\section{Host Reactions of Sweetpotato Genotypes to Root-knot Nematodes and Variation in Virulence of Meloidogyne incognita Populations}

\author{
J.C. Cervantes-Flores and G.C. Yencho ${ }^{1}$ \\ Department of Horticultural Science, North Carolina State University, Raleigh, \\ NC 27695
}

\section{E.L. Davis \\ Department of Plant Pathology, North Carolina State University, Raleigh, NC 27695}

Additional index words. Ipomoea batatas, Meloidogyne arenaria, Meloidogyne javanica, host plant resistance, differential hosts, plant breeding

\begin{abstract}
Sweetpotato [Ipomoea batatas (L.) Lam.] genotypes were evaluated for resistance to North Carolina root-knot nematode populations: Meloidogyne arenaria $(\mathrm{Neal})$ Chitwood races 1 and 2; $M$. incognita (Kofoid \& White) Chitwood races 1, 2, 3, and 4; and $M$. javanica (Treub) Chitwood. Resistance screening was conducted using $150-\mathrm{cm}^{3}$ Conetainers containing 3 sand : 1 soil mix. Nematode infection and reproduction were assessed as the number of egg masses produced by root-knot nematodes per root system. Host suitability for the root-knot nematode populations differed among the 27 sweetpotato genotypes studied. Five genotypes ('Beauregard', L86-33, PDM P6, 'Porto Rico', and 'Pelican Processor') were selected for further study based on their differential reaction to the different root-knot nematodes tested. Two African landraces ('Tanzania' and 'Wagabolige') were also selected because they were resistant to all the nematode species tested. The host status was tested against the four original $M$. incognita races, and an additional eight populations belonging to four host races, but collected from different geographical regions. The virulence of root-knot nematode populations of the same host race varied among and within sweetpotato genotypes. 'Beauregard', L86-33, and PDM P6 were hosts for all $12 \mathrm{M}$. incognita populations, but differences in the aggressiveness of the isolates were observed. 'Porto Rico' and 'Pelican Processor' had different reactions to the $M$. incognita populations, regardless of the host race. Several clones showed resistance to all $M$. incognita populations tested. These responses suggest that different genes could be involved in the resistance of sweetpotato to root-knot nematodes. The results also suggest that testing Meloidogyne populations against several different sweetpotato hosts may be useful in determining the pathotypes affecting sweetpotato.
\end{abstract}

The worldwide distribution of root-knot nematodes (Meloidogyne species), their extensive host plant ranges, and their interactions with pathogenic fungi and bacteria in plant disease complexes rank root-knot nematodes among the major pathogens affecting crops (Sasser, 1980). Root-knot nematodes cause significant reductions in the yield and quality of storage roots in sweetpotato (Clark et al., 1992). In North Carolina, losses of sweetpotato due to root-knot nematode were estimated at 6\% in 1991 (Toth et al., 1996).

Received for publication 6 Sept. 2001. Accepted for publication $28 \mathrm{Apr}$. 2002. This paper is a portion of a MS thesis submitted by Jim C. Cervantes-Flores. The research was supported by the North Carolina Sweetpotato Commission and the Fulbright Commission. We thank William Swallow for his statistical guidance, Rebeca Rufty for her valuable discussions, and Ken Pecota and Cindy Pierce for assistance with the greenhouse work. We also thank the anonymous reviewers whose comments helped to improve the manuscript.

${ }^{1}$ To whom reprint requests should be addressed. E-mail address: Craig_Yencho@NCSU.edu
Root-knot nematode symptoms on sweetpotato include round- to spindle-shaped swellings (galls) on fibrous roots and cracks on fleshy storage roots (Lawrence et al., 1986). In countries where sweetpotato is a low-value staple crop, the use of resistant cultivars may be the only economically practical management alternative (Roberts, 1992). Accurate identification of the root-knot nematode species and races damaging a crop is important for the selection of nematode management strategies, especially if host plant resistance is to be used (Sasser and Carter, 1985).

More than 50 species of root-knot nematodes have been described, but Meloidogyne incognita, $M$. javanica, $M$. arenaria, and $M$. hapla Chitwood account for more than $95 \%$ of the species detected in agricultural soils worldwide (Roberts, 1995; Sasser and Carter, 1985; Taylor et al., 1982). Four host races have been recognized in $M$. incognita and two in $M$. arenaria. These races were proposed based on the ability or inability of a root-knot nematode population to reproduce in the North Carolina Differential Host Test (Hartman and Sasser,
1985). However, the assignment of these races was based on a particular set of host plants that does not include sweetpotato. Moreover, molecular, biochemical or morphological markers for the differentiation of host races within the species of Meloidogyne have not been found yet (Roberts, 1995).

The genetics of resistance to root-knot nematodes in sweetpotato is poorly understood. Cordner et al. (1954) and Giamalva et al. (1961) indicated that root-knot nematode resistance segregated quantitatively and that a relatively large number of genes were involved. Likewise, Struble et al. (1966) suggested that root-knot nematode resistance in sweetpotato might be inherited as multiple factors, not as simple Mendelian characters. Jones and Dukes (1980) studied the inheritance of resistance in sweetpotato to $M$. incognita and $M$. javanica, using three measures of resistance (number of egg masses, root-gall index, and root-necrosis index) and reported narrow-sense heritability $\left(\mathrm{h}^{2}\right)$ estimates of 0.69 , 0.78 , and 0.72 , respectively. They found that resistance to the two species was not correlated, and suggested independent inheritance involving different genes. In a recent study, Ukoskit et al. (1997) hypothesized that resistance to root-knot nematodes was inherited qualitatively, and using random amplified polymorphic DNA (RAPD) identified a single RAPD marker $\left(\mathrm{OP} 15_{1500}\right)$ linked to root-knot nematode resistance in a cross between a resistant ('Regal') and a susceptible ('Vardaman') sweetpotato.

Because the success of a breeding program designed to develop sweetpotatoes with resistance to root-knot nematode depends on the identification of suitable resistance genes, it is important to increase our understanding of nematode resistance in sweetpotato, and when possible, to improve methods of nematode resistance evaluations in sweetpotato. The objectives of this study were to assess the resistance response of sweetpotato genotypes to $M$. incognita, M. arenaria, and $M$. javanica, and to assess the variability in the virulence of $M$. incognita populations collected from different areas worldwide on a set of sweetpotato genotypes differing in resistance/susceptibility. This work will provide a better understanding of the relationships between sweetpotato host status and Meloidogyne populations, and identify sweetpotato genotypes that can be used as sources of root-knot nematode resistance genes.

\section{Materials and Methods}

Differential response of sweetpotato genotypes to Meloidogyne sp.

Experiment 1. Twenty-six sweetpotato genotypes of economic importance or present in the pedigree of modern cultivars (Table 1), were evaluated for resistance to greenhousecultured North Carolina populations of Meloidogyne arenaria (races 1 and 2), $M$. incognita (races 1,2,3, and 4), and M. javanica as classified by the NC Differential Host Test (Hartman and Sasser, 1985). Five 15-cm-long 
Table 1. Pedigree of the sweetpotato (Ipomoea batatas) genotypes evaluated for resistance to root-knot nematodes Meloidogyne arenaria races 1 and 2, $M$. incognita races $1,2,3$ and 4, and $M$. javanica.

\begin{tabular}{|c|c|}
\hline Genotype & Pedigree $^{z}$ \\
\hline Beauregard & L78-21>L70-197>L67-69>L59-89 \\
\hline Carogold & Unknown \\
\hline Centennial & L-130>(Unit 1 PR x Pelican Processor) \\
\hline Eureka & L9-163>L0-132(Centennial $x$ Unit 1 PR) \\
\hline Excel & Regal \\
\hline Heartogold & Mameyita $x$ Yellow Yam \\
\hline Hernandez & $\mathrm{L} 70-323>\mathrm{L} 63-217>\mathrm{L} 41-212$ \\
\hline Jewel & Centennial $x$ Nugget \\
\hline L86-33 & Beauregard \\
\hline Nancy Hall & Unknown \\
\hline Nugget & $\begin{array}{l}\text { NC-124[NC-53(Tinian) } x \text { NC-65(NC-41 x NC-24)] } \\
\quad \text { x NC-63[NC-41(SC32-149 x 6-42-1) } \\
\quad \text { x NC-1(B5965)] }\end{array}$ \\
\hline PDM P4 & Plant Introduction from Southeast Asia \\
\hline PDM P6 & Plant Introduction from Southeast Asia \\
\hline Pelican Processor & Americano \\
\hline Porto Rico & PR varieties (derived from Mameyita) \\
\hline Regal & W-99 \\
\hline Resisto & W-56 (derived from I/6 USDA population ${ }^{y}$ ) \\
\hline Southern Delite & W-99 \\
\hline Tanzania & Ugandan landrace \\
\hline Tinian & Plant Introduction from Tinian, Mariana Islands \\
\hline Triumph & Unknown \\
\hline W-99 & SC-1166 \\
\hline $\mathrm{W}-271$ & Unknown \\
\hline W-274 & $\mathrm{W}-233$ \\
\hline $\mathrm{W}-250$ & Unknown \\
\hline Wagabolige & Ugandan landrace \\
\hline $\begin{array}{l}\text { "Parents shown } \\
\text { parent shown is } \\
\text { yMass selected p } \\
\text { program (Jones }\end{array}$ & $\begin{array}{l}\text { after a ">" represent an open-pollination cross (the } \\
\text { nal parent and the male parent is unknown). } \\
\text { created by the USDA-ARS sweetpotato breeding }\end{array}$ \\
\hline
\end{tabular}

cuttings per sweetpotato genotype were transplanted into $150-\mathrm{cm}^{3}$ Conetainers (Stuewe \& Sons, Corvallis, Ore.), containing a $3: 1$ pasteurized mix (by volume) of coarse sand and field soil (loamy sand: $88.9 \%$ sand, $8.3 \%$ silt, and $2.8 \%$ clay), respectively. Root-knot nematodes were cultured on 'Rutgers' tomato plants (Lycopersicon esculentum Mill.). Nematode eggs were extracted using $0.6 \% \mathrm{NaOCl}$ (Hussey and Barker, 1973). About 10,000 eggs were injected into the soil surrounding the roots of each plant 2 weeks after planting. Plants were grown in the greenhouse at 25 to $28^{\circ} \mathrm{C}$ and watered as needed.

Plants were harvested at $56 \mathrm{~d}$ after inoculation. Roots were stained with phloxine B, as described by Daykin and Hussey (1985), and host suitability was evaluated by counting the number of egg masses (EM) present on the root system. To qualitatively assess the host status of the sweetpotato genotypes, a mean value of $10 \mathrm{EM}$ or more per root system was considered as a positive host plant reaction as used by Hartman and Sasser (1985) to assess host suitability in the NC Differential Host Test. Each nematode population was arranged in a completely randomized design with five replications per genotype, and the experiments were replicated five times over time. Numbers of egg mass per root system were transformed by $\sqrt{(x+0.5)}$, and the analysis of variance (ANOVA) was performed on each population using PROC GLM (SAS Institute, Cary, N.C.). Means were separated using the WallerDuncan $k$-ratio $t$-test $(k$-ratio $=100)$ procedure $(\alpha=0.05)$.
Experiment 2. Based on the results of the above experiments, a subset of sweetpotato genotypes responding differentially to the nematode populations was selected (Table 3 ) and a second series of experiments conducted using the same procedures described earlier. Data were transformed by $\sqrt{(x+0.5)}$ and the data were analyzed by ANOVA. To augment the analysis, nematode populations overlapping in experiments 1 and 2 were incorporated in the analyses as replications conducted over time. Means were separated using the WallerDuncan $k$-ratio $t$-test $(k$-ratio $=100)$ procedure $(\alpha=0.05)$, and the best set of sweetpotato genotypes that had a different host reaction for the Meloidogyne species were selected. Backtransformed data are presented in tables for clarity.

Nematode population variation experiment. Eight $M$. incognita populations (race 1 from Africa and China, race 2 from Trinidad and Nigeria, race 3 from Uruguay and Louisiana, and race 4 from Texas and Ghana) kept under cryo-preservation from the collections of the International Meloidogyne Project (Hartman and Sasser, 1985) were thawed and cultured on 'Rutgers' tomatoes. Along with these eight, the four host races of $M$. incognita described in the previous tests were included and their host interactions with the sweetpotato genotypes selected from the first series of experiments tested using our screening procedures. To check the viability and pathogenicity of the nematode populations 'Rutgers' tomatoes were also inoculated. The experiment was conducted twice with each replication being arranged in a completely randomized design by nematode population with five plants per sweetpotato genotype. Data were transformed by $\sqrt{(x+0.5)}$ and analyzed with ANOVA using SAS (SAS Institute, Cary, N.C.). To assess nematode interpopulation variation statistical analyses were conducted on each $M$. incognita race group. Means were separated using the Fisher's LSD procedure $(\alpha=0.05)$. Back-transformed data are presented in tables for clarity.

\section{Results}

Differential response of sweetpotato genotypes. The initial screen of the 26 sweetpotato genotypes demonstrated that host status was dependent on the Meloidogyne species and race evaluated (Table 2). Sweetpotato genotype was significant $(P<0.001)$ for each Meloidogyne species. All nematode populations infected at least one sweetpotato genotype, with the exception of $M$. arenaria race 1 . Meloidogyne arenaria race 1 infected and reproduced slightly on only L86-33. In contrast, Meloidogyne arenaria race 2 reproduced successfully on L86-33 (38 EM per root system) but relatively poorly on 'Nancy Hall' (9 egg masses per root system). Only L86-33 was a host for all of the other five Meloidogyne populations. 'Beauregard' was susceptible to $M$. incognita races $1,2,3$, and 4 , and $M$. javanica. The other cultivars varied in response depending on the nematode population. For example, 'Pelican Processor' was a host for only $M$. incognita race 2 . Likewise, sweetpotato genotypes 'Excel', 'Triumph', 'Regal', 'Tinian', 'Resisto', 'Tanzania', and 'Wagabolige' were hosts for only a limited number of Meloidogyne populations (Table 2).

Due to their different responses to the Meloidogyne populations tested, 'Beauregard', 'Centennial', 'Eureka', 'Jewel', L86-33, 'Nancy Hall', PDM P6, 'Pelican Processor', 'Porto Rico', 'Tanzania', 'Triumph', and 'Wagabolige' were selected for further testing (Table 3). There were no significant differences due to experiment $(P<0.05)$ when the two experiments were combined. Further, the results observed in the first experiment were confirmed in the second (Table 3).

Meloidogyne incognita race 1 (Table 3) produced the greatest number of EM on 'Centennial' and 'Porto Rico', but also infected 'Beauregard', 'Eureka', L86-33, 'Nancy Hall', and PDM P6. 'Centennial', 'Pelican Processor' and 'Porto Rico' were very suitable hosts for $M$. incognita race 2 (Table 3 ). In contrast, 'Jewel', 'Tanzania', and 'Wagabolige' were not hosts for $M$. incognita race 2. Meloidogyne incognita race 3 produced the greatest number of EM on 'Porto Rico' and 'Centennial', but failed to infect 'Pelican Processor', 'Tanzania', 'Triumph', and 'Wagabolige' (Table 3). 'Beauregard', PDM P6, 'Nancy Hall', and L86-33 were hosts for $M$. incognita race 4 (Table 3). All other cultivars, except 'Jewel', were non-hosts for this nematode population. L86-33, 'Nancy Hall', and 'Beauregard' were good hosts for M. javanica compared to 'Jewel' and 'Eureka', which were only slightly in- 
Table 2. Host status of 26 sweetpotato genotypes for selected North Carolina populations ${ }^{2}$ of Meloidogyne (Test 1).

\begin{tabular}{|c|c|c|c|c|c|c|c|c|c|c|c|c|c|c|}
\hline \multirow[b]{2}{*}{ Cultivars } & \multicolumn{2}{|c|}{$\begin{array}{c}\text { M. arenaria } \\
\text { race } 1\end{array}$} & \multicolumn{2}{|c|}{$\begin{array}{l}\text { M. arenaria } \\
\text { race } 2\end{array}$} & \multicolumn{2}{|c|}{$\begin{array}{l}\text { M. incognita } \\
\text { race } 1\end{array}$} & \multicolumn{2}{|c|}{$\begin{array}{l}\text { M. incognita } \\
\text { race } 2\end{array}$} & \multicolumn{2}{|c|}{$\begin{array}{l}\text { M. incognita } \\
\text { race } 3\end{array}$} & \multicolumn{2}{|c|}{$\begin{array}{l}\text { M. incognita } \\
\text { race } 4\end{array}$} & \multicolumn{2}{|c|}{ M. javanica } \\
\hline & $\overline{\mathrm{EM}^{\mathrm{y}}}$ & $\overline{S D D^{x}}$ & EM & $\overline{\mathrm{SD}}$ & EM & $\overline{\mathrm{SD}}$ & EM & $\overline{S D}$ & EM & $\overline{\mathrm{SD}}$ & EM & $\overline{\mathrm{SD}}$ & EM & $\mathrm{SD}$ \\
\hline Beauregard & $0 b^{w}$ & 0 & $0 \mathrm{c}$ & 0 & $39 \mathrm{~b}$ & 1.2 & $27 \mathrm{~cd}$ & 1.2 & $5 \mathrm{de}$ & 0.7 & $22 \mathrm{a}$ & 1 & $24 \mathrm{a}$ & 0.5 \\
\hline Carogold & $0 \mathrm{~b}$ & 0 & $0 \mathrm{c}$ & 0 & 0 ef & 0 & $0 \mathrm{~g}$ & 0 & $0 \mathrm{f}$ & 0 & $0 \mathrm{f}$ & 0 & $0 \mathrm{~d}$ & 0 \\
\hline Centennial & $0 \mathrm{~b}$ & 0 & $0 \mathrm{c}$ & 0 & $52 \mathrm{~b}$ & 5.3 & $90 \mathrm{a}$ & 6 & $41 \mathrm{a}$ & 2.7 & $0 \mathrm{f}$ & 0 & $0 \mathrm{~d}$ & 0 \\
\hline Eureka & $0 \mathrm{~b}$ & 0 & $0 \mathrm{c}$ & 0 & $23 c$ & 3 & $11 \mathrm{e}$ & 7 & $12 \mathrm{bc}$ & 4.2 & $0 \mathrm{f}$ & 0 & $0 \mathrm{~d}$ & 0 \\
\hline Excel & $0 \mathrm{~b}$ & 0 & $0 \mathrm{c}$ & 0 & 0 ef & 0 & $0 \mathrm{~g}$ & 0 & $0 \mathrm{f}$ & 0 & $0 \mathrm{f}$ & 0 & $0 \mathrm{~d}$ & 0 \\
\hline Heartogold & $0 \mathrm{~b}$ & 0 & $0 \mathrm{c}$ & 0 & $0 \mathrm{ef}$ & 0 & $0 \mathrm{~g}$ & 0 & $4 \mathrm{de}$ & 2.9 & $3 \mathrm{bcd}$ & 0.7 & $0 \mathrm{~d}$ & 0 \\
\hline Hernandez & $0 \mathrm{~b}$ & 0 & $0 \mathrm{c}$ & 0 & $1 \mathrm{ef}$ & 0.1 & $1 \mathrm{~g}$ & 0.7 & $2 \mathrm{ef}$ & 0.2 & $0 \mathrm{f}$ & 0 & $0 \mathrm{~d}$ & 0 \\
\hline Jewel & $0 \mathrm{~b}$ & 0 & $0 \mathrm{c}$ & 0 & 1 ef & 0.3 & $1 \mathrm{~g}$ & 0.1 & $7 \mathrm{~cd}$ & 0.7 & 2 cde & 0.8 & $2 \mathrm{c}$ & 0.6 \\
\hline L86-33 & $3 a$ & 1.6 & $38 \mathrm{a}$ & 0.2 & $22 \mathrm{c}$ & 4.2 & $2 \mathrm{fg}$ & 1 & $13 \mathrm{bc}$ & 1.3 & $6 \mathrm{~b}$ & 2.1 & $24 \mathrm{a}$ & 0.2 \\
\hline Nancy Hall & $0 \mathrm{~b}$ & 0 & $9 \mathrm{~b}$ & 0.7 & $21 \mathrm{c}$ & 3.3 & $16 \mathrm{de}$ & 1 & $15 \mathrm{~b}$ & 0.9 & $18 \mathrm{a}$ & 0.7 & $21 \mathrm{a}$ & 2.1 \\
\hline Nugget & $0 \mathrm{~b}$ & 0 & $0 \mathrm{c}$ & 0 & $1 \mathrm{ef}$ & 0.1 & $0 \mathrm{~g}$ & 0 & $0 \mathrm{f}$ & 0 & 1 def & 0.1 & $3 \mathrm{~b}$ & 0 \\
\hline PDM P4 & $0 \mathrm{~b}$ & 0 & $0 \mathrm{c}$ & 0 & $0 \mathrm{f}$ & 0 & $0 \mathrm{~g}$ & 0 & $0 \mathrm{f}$ & 0 & $0 \mathrm{f}$ & 0 & $0 \mathrm{~d}$ & 0 \\
\hline PDM P6 & $0 \mathrm{~b}$ & 0 & $0 \mathrm{c}$ & 0 & $19 \mathrm{c}$ & 0.8 & 8 ef & 0.9 & $2 \mathrm{ef}$ & 0.6 & $18 \mathrm{a}$ & 5.5 & $0 \mathrm{~d}$ & 0 \\
\hline Pelican Processor & $0 \mathrm{~b}$ & 0 & $0 \mathrm{c}$ & 0 & $0 \mathrm{f}$ & 0 & $36 \mathrm{c}$ & 1.1 & $0 \mathrm{f}$ & 0 & $0 \mathrm{f}$ & 0 & $0 \mathrm{~d}$ & 0 \\
\hline Porto Rico & $0 \mathrm{~b}$ & 0 & $0 \mathrm{c}$ & 0 & $85 \mathrm{a}$ & 4.8 & $60 \mathrm{~b}$ & 7.7 & $50 \mathrm{a}$ & 6.1 & $0 \mathrm{f}$ & 0 & $0 \mathrm{~d}$ & 0 \\
\hline Regal & $0 \mathrm{~b}$ & 0 & $0 \mathrm{c}$ & 0 & $0 \mathrm{f}$ & 0 & $0 \mathrm{~g}$ & 0 & $0 \mathrm{f}$ & 0 & $0 \mathrm{f}$ & 0 & $0 \mathrm{~d}$ & 0 \\
\hline Resisto & $0 \mathrm{~b}$ & 0 & $0 \mathrm{c}$ & 0 & $0 \mathrm{f}$ & 0 & $0 \mathrm{~g}$ & 0 & $0 \mathrm{f}$ & 0 & $0 \mathrm{f}$ & 0 & $0 \mathrm{~d}$ & 0 \\
\hline Southern Delite & $0 \mathrm{~b}$ & 0 & $0 \mathrm{c}$ & 0 & $1 \mathrm{ef}$ & 0.3 & $3 \mathrm{fg}$ & 4.4 & $0 \mathrm{f}$ & 0 & $5 \mathrm{bc}$ & 4.4 & $0 \mathrm{~d}$ & 0 \\
\hline Tanzania & $0 \mathrm{~b}$ & 0 & $0 \mathrm{c}$ & 0 & $7 \mathrm{~d}$ & 0.3 & $1 \mathrm{~g}$ & 0.1 & $0 \mathrm{f}$ & 0 & 0 ef & 0 & $0 \mathrm{~d}$ & 0 \\
\hline Tinian & $0 \mathrm{~b}$ & 0 & $0 \mathrm{c}$ & 0 & $0 \mathrm{f}$ & 0 & $0 \mathrm{~g}$ & 0 & $0 \mathrm{f}$ & 0 & $0 \mathrm{f}$ & 0 & $0 \mathrm{~d}$ & 0 \\
\hline Triumph & $0 \mathrm{~b}$ & 0 & $0 \mathrm{c}$ & 0 & $0 \mathrm{ef}$ & 0 & $7 \mathrm{ef}$ & 0.3 & $0 \mathrm{f}$ & 0 & $0 \mathrm{ef}$ & 0 & $0 \mathrm{~d}$ & 0 \\
\hline W 99 & $0 \mathrm{~b}$ & 0 & $0 \mathrm{c}$ & 0 & $3 \mathrm{de}$ & 0.4 & $0 \mathrm{~g}$ & 0 & $2 \mathrm{ef}$ & 0.3 & $1 \mathrm{ef}$ & 0.1 & $0 \mathrm{~d}$ & 0 \\
\hline W 250 & $0 \mathrm{~b}$ & 0 & $0 \mathrm{c}$ & 0 & $0 \mathrm{f}$ & 0 & $1 \mathrm{~g}$ & 0.3 & $0 \mathrm{f}$ & 0 & $0 \mathrm{f}$ & 0 & $0 \mathrm{~d}$ & 0 \\
\hline W 271 & $0 \mathrm{~b}$ & 0 & $0 \mathrm{c}$ & 0 & $0 \mathrm{f}$ & 0 & $0 \mathrm{~g}$ & 0 & $0 \mathrm{f}$ & 0 & $0 \mathrm{f}$ & 0 & $0 \mathrm{~d}$ & 0 \\
\hline W 274 & $0 \mathrm{~b}$ & 0 & $0 \mathrm{c}$ & 0 & $0 \mathrm{f}$ & 0 & $2 \mathrm{fg}$ & 0.8 & $0 \mathrm{f}$ & 0 & $0 \mathrm{f}$ & 0 & $0 \mathrm{~d}$ & 0 \\
\hline Wagabolige & $0 \mathrm{~b}$ & 0 & $0 \mathrm{c}$ & 0 & $0 \mathrm{ef}$ & 0 & $0 \mathrm{~g}$ & 0 & $0 \mathrm{f}$ & 0 & $1 \mathrm{def}$ & 0.2 & $0 \mathrm{~d}$ & 0 \\
\hline
\end{tabular}

'Populations maintained in pure greenhouse culture on 'Rutgers' tomato and race determined by NC Differential Host Test (Hartman and Sasser, 1985).

${ }^{y}$ Egg mass (EM) number per root system. Table values are the back-transformed mean of five replications per cultivar. Transformation used for data analysis was $\sqrt{(x+0.5)}$.

${ }^{\mathrm{x}}$ Standard deviation for egg mass values.

${ }^{\text {w}}$ Means within the same column followed by the same letter are not significantly different (Waller-Duncan $k$-ratio $t$-test, $k=100$ ).

Table 3. Host status of selected sweetpotato genotypes to North Carolina populations ${ }^{\mathrm{z}}$ of Meloidogyne.

\begin{tabular}{|c|c|c|c|c|c|c|c|c|c|c|c|c|c|c|}
\hline \multirow[b]{2}{*}{ Genotype } & \multicolumn{2}{|c|}{$\begin{array}{l}\text { M. arenaria } \\
\text { race } 1\end{array}$} & \multicolumn{2}{|c|}{$\begin{array}{l}\text { M. arenaria } \\
\text { race } 2 \\
\end{array}$} & \multicolumn{2}{|c|}{$\begin{array}{l}\text { M. incognita } \\
\text { race } 1 \\
\end{array}$} & \multicolumn{2}{|c|}{$\begin{array}{l}\text { M. incognita } \\
\text { race } 2 \\
\end{array}$} & \multicolumn{2}{|c|}{$\begin{array}{l}\text { M. incognita } \\
\text { race } 3 \\
\end{array}$} & \multicolumn{2}{|c|}{$\begin{array}{l}\text { M. incognita } \\
\text { race } 4\end{array}$} & \multicolumn{2}{|c|}{ M. javanica } \\
\hline & $\mathrm{EM}^{\mathrm{y}}$ & $\mathrm{SE}^{\mathrm{x}}$ & EM & SE & EM & SE & EM & SE & EM & SE & EM & SE & EM & SE \\
\hline Beauregard & $0 \mathrm{~b}^{w}$ & 0 & $0 \mathrm{c}$ & 0 & $24 \mathrm{~b}$ & 0.5 & $24 b$ & 0.2 & $16 \mathrm{~cd}$ & 0.5 & $34 \mathrm{a}$ & 0.4 & $29 \mathrm{~b}$ & 0.1 \\
\hline Centennial & $0 \mathrm{~b}$ & 0 & $0 \mathrm{c}$ & 0 & $48 \mathrm{a}$ & 0.6 & $45 \mathrm{a}$ & 1.2 & $29 \mathrm{ab}$ & 0.3 & $0 \mathrm{~d}$ & 0 & $0 \mathrm{~d}$ & 0 \\
\hline Eureka & $0 \mathrm{~b}$ & 0 & $0 \mathrm{c}$ & 0 & $26 \mathrm{~b}$ & 0.6 & $14 \mathrm{bc}$ & 0.4 & $23 \mathrm{bc}$ & 0.5 & $1 \mathrm{~cd}$ & 0 & $3 \mathrm{c}$ & 0.5 \\
\hline Jewel & $0 \mathrm{~b}$ & 0 & $0 \mathrm{c}$ & 0 & $1 \mathrm{c}$ & 0 & $2 \mathrm{~d}$ & 0 & $5 \mathrm{e}$ & 0.1 & $3 c$ & 0.1 & $4 \mathrm{c}$ & 0.1 \\
\hline L86-33 & $5 \mathrm{a}$ & 0.1 & $44 \mathrm{a}$ & 0.2 & $17 \mathrm{~b}$ & 0.3 & $3 \mathrm{~d}$ & 0.1 & $10 \mathrm{de}$ & 0.1 & $15 \mathrm{~b}$ & 0.3 & $48 \mathrm{a}$ & 0.6 \\
\hline Nancy Hall & $0 \mathrm{~b}$ & 0 & $8 \mathrm{~b}$ & 0.1 & $18 \mathrm{~b}$ & 0.2 & $25 \mathrm{~b}$ & 0.2 & $19 \mathrm{bc}$ & 0.2 & $30 \mathrm{a}$ & 0.4 & $36 \mathrm{~b}$ & 0.5 \\
\hline PDM P6 & $0 \mathrm{~b}$ & 0 & $0 \mathrm{c}$ & 0 & $26 \mathrm{~b}$ & 0.2 & $16 \mathrm{bc}$ & 0.3 & $14 \mathrm{~cd}$ & 0.6 & $32 \mathrm{a}$ & 0.7 & $0 \mathrm{~d}$ & 0 \\
\hline Pelican Processor & $0 \mathrm{~b}$ & 0 & $0 \mathrm{c}$ & 0 & $0 \mathrm{c}$ & 0 & $42 \mathrm{a}$ & 0.1 & $0 \mathrm{f}$ & 0 & $0 \mathrm{~d}$ & 0 & $0 \mathrm{~d}$ & 0 \\
\hline Porto Rico & $0 \mathrm{~b}$ & 0 & $0 \mathrm{c}$ & 0 & $47 \mathrm{a}$ & 0.9 & $40 \mathrm{a}$ & 0.7 & $38 \mathrm{a}$ & 0.4 & $0 \mathrm{~d}$ & 0 & $0 \mathrm{~d}$ & 0 \\
\hline Tanzania & $0 \mathrm{~b}$ & 0 & $0 \mathrm{c}$ & 0 & $3 c$ & 0.1 & $1 \mathrm{~d}$ & 0 & $0 \mathrm{f}$ & 0 & $1 \mathrm{~cd}$ & 0 & $0 \mathrm{~d}$ & 0 \\
\hline Triumph & $0 \mathrm{~b}$ & 0 & $0 \mathrm{c}$ & 0 & $0 \mathrm{c}$ & 0 & $11 \mathrm{c}$ & 0.2 & $0 \mathrm{f}$ & 0 & $0 \mathrm{~d}$ & 0 & $0 \mathrm{~d}$ & 0 \\
\hline Wagabolige & $0 \mathrm{~b}$ & 0 & $0 \mathrm{c}$ & 0 & $0 \mathrm{c}$ & 0 & $0 \mathrm{~d}$ & 0 & $0 \mathrm{f}$ & 0 & $1 \mathrm{~cd}$ & 0 & $0 \mathrm{~d}$ & 0 \\
\hline
\end{tabular}

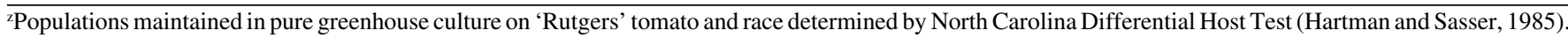
${ }^{y}$ Egg mass (EM) number per root system. Table values are the back-transformed mean of two tests of five replications each. Transformation used for data analysis was $\sqrt{(x+0.5)}$.

${ }^{\mathrm{x}}$ Standard error of the mean number of EM per root system.

${ }^{\text {w}}$ Means within a column followed by the same letter are not significantly different (Waller-Duncan $k$-ratio $t$-test, $k=100$ ).

fected (Table 3). All the other cultivars were non-hosts for M. javanica.

Nematode population variation. To examine host responses of a diverse set of nematode populations 'Beauregard', L86-33, PDM P6, 'Porto Rico', and 'Pelican Processor' were selected for further testing against the 12 nematode populations (Table 4 ). There were no significant differences due to time $(P<0.05)$ when the two experiments were combined Analysis of the combined data showed that cultivar, site of nematode origin, and cultivar $\times$ site interaction had significant $(P<0.001)$ effects on $M$. incognita infection of sweetpotato. Variation in host status was dependent on the sweetpotato genotype and the nematode population evaluated, and it did not necessarily correspond to the designated nematode host race.

Due to problems with the increase of the population from China, only two populations of $M$. incognita race 1 were evaluated in the second test. Since data from both tests did not differ, results on the population from China were drawn from test 1 only. 'Beauregard' and PDM P6 were infected by the three $M$. incognita race 1 populations from different geographical origins. In contrast, L86-33 and 'Porto Rico' had different reactions to the $M$. incognita race 1 populations. 'Pelican Proces- sor' was a non-host for $M$. incognita race 1 . 'Beauregard' was infected by the three $M$. incognita race 2 populations, but L86-33 was minimally infected. PDM P6, 'Pelican Processor' and 'Porto Rico' had differential response to the $M$. incognita race 2 populations. It should be noted that the EM values and host status of L86-33 for M. incognita race 2 and PDM P6 for $M$. incognita race 3 in the preliminary tests (Table 3 ) were not consistent with the values observed in the nematode population variation tests (Table 5). We are not sure why this occurred. 'Beauregard' was susceptible to the three $M$. incognita race 3 populations. L86-33 was a host for the three $M$. 
Table 4. Selected sweetpotato genotypes ${ }^{\mathrm{z}}$ and their quantitative ${ }^{\mathrm{y}}$ and qualitative response ${ }^{\mathrm{x}}$ to different Meloidogyne populations. ${ }^{\text {" }}$

\begin{tabular}{lcrrrr}
\hline \hline Root-knot nematode & \multicolumn{5}{c}{ Sweetpotato genotype } \\
\cline { 2 - 6 } (race) & Beauregard & L86-33 & PDM P6 & Porto Rico & Pelican Processor \\
\hline M. arenaria 2 & $0^{\mathrm{x}}(-)^{\mathrm{w}}$ & $43(+)$ & $0(-)$ & $0(-)$ & $0(-)$ \\
M. incognita 1 & $24(+)$ & $17(+)$ & $26(+)$ & $47(+)$ & $0(-)$ \\
M. incognita 2 & $24(+)$ & $3(-)$ & $16(+)$ & $40(+)$ & $42(+)$ \\
M. incognita 3 & $16(+)$ & $10(+)$ & $14(+)$ & $38(+)$ & $0(-)$ \\
M. incognita 4 & $34(+)$ & $15(+)$ & $32(+)$ & $0(-)$ & $0(-)$ \\
M. javanica & $29(+)$ & $48(+)$ & $0(-)$ & $0(-)$ & $0(-)$ \\
\hline
\end{tabular}

${ }^{2}$ Sweetpotato genotypes selected for their differential response to different Meloidogyne species and races ${ }^{y}$ Number of egg masses produced by the nematodes per root system. Values shown are the back-transformed means. Transformation used for data analysis was $\sqrt{(x+0.5)}$.

${ }^{x}$ Host status considered as (+) if the number of egg masses per root system were $\geq 10$, and $(-)$ if $\leq 10$, as used by the NC Differential Host Test (Hartman and Sasser, 1985).

wMeloidogyne populations were obtained from the Nematology program at North Carolina State Univ., Raleigh. Race classification of Meloidogyne was in accordance with the NC Differential Host Test (Hartman and Sasser, 1985). No sweetpotato genotypes were hosts for race 1 of M. arenaria.

incognita race 3 populations, but the $M$. incognita race 3 population from North Carolina was the least aggressive. 'Pelican Processor' was a non-host for the three $M$. incognita race 3 populations. 'Beauregard', L86-33, and PDM P6 were hosts for the three $M$. incognita race 4 populations and did not distinguish among the different populations. 'Pelican Processor' was a host for the $M$. incognita race 4 populations from Texas and Ghana, with the population from Ghana being more aggressive. In contrast, 'Porto Rico' was a host only for $M$. incognita race 4 from Ghana.

Overall, 'Beauregard' was the most susceptible of the genotypes evaluated, being a host for all the $M$. incognita populations tested. L86-33 and PDM P6 were also hosts for almost all $M$. incognita populations tested, but the infection was generally lower than in 'Beauregard' (Table 5). 'Pelican Processor' and 'Porto Rico' had a differential reaction to the $M$. incognita populations, being hosts only for certain isolates of the host races (Table 5). Also, 'Tanzania' and 'Wagabolige' were evalu- ated for their resistance to these 12 populations of nematodes, and both of these sweetpotato genotypes were non-hosts for all $M$. incognita populations tested.

\section{Discussion}

In general, our results agree with those observed in similar studies (Bonsi and Phills, 1979; Cervantes-Flores et al., 2000; Giamalva et al., 1963). Sweetpotato root-knot nematode host status is dependent on sweetpotato genotype and Meloidogyne population. The results of the evaluations of Meloidogyne populations from North Carolina suggest that there are probably several different genes and/or alleles in the germplasm evaluated that are associated with the resistance to different Meloidogyne species and races. The complexity of these associations can be observed in the response of L86-33 to $M$. arenaria race 2 and $M$. arenaria race 1. Meloidogyne arenaria race 2 is relatively aggressive on L86-33 compared to $M$. arenaria race 1. Also, 'Pelican Processor,' which supported a relatively high population of $M$. incognita race 2, was not a host for any other Meloidogyne incognita population from North Carolina. Netscher and Taylor (1979) also observed that sweetpotatoes did not have a uniform response to populations of the same species of Meloidogyne.

It is interesting to note that $M$. arenaria has been observed to be an aggressive pathogen of many plant species (Davis et al., 1988, 1998). Our results, however, appear to confirm that resistance to $M$. arenaria might be commonly found in many sweetpotato genotypes. Cervantes-Flores et al. (2000) in a companion study, did not observe infection in several sweetpotato cultivars by $M$. arenaria race 2 . Similarly, Giamalva et al. (1963) did not observe $M$. arenaria developing to mature females on several sweetpotato varieties.

Breeding for resistance to $M$. javanica, the second most common root-knot nematode found in cultivated lands worldwide, but especially in the tropics (Sasser, 1980; Taylor et al., 1982), may also not be a problem in sweetpotato, since good sources of resistance were observed in most genotypes evaluated. However, 'Beauregard', L86-33, and 'Nancy Hall' were highly susceptible to $M$. javanica. This situation is important because 'Beauregard' and 'Nancy Hall' have been used as parents widely in many sweetpotato breeding programs. To date, distinct host races of $M$. javanica have not been identified using the NCDifferential Host Test (Hartman and Sasser, 1985). However, Sasser (1980) observed that a few populations of $M$. javanica parasitize the NC Differential Host, 'California Wonder' pepper, and, similarly, some populations of $M$. javanica have been observed to reproduce on peanut (K. Barker, personal communications).

Surprisingly, 'Beauregard' was a host for all $12 \mathrm{M}$. incognita populations, and this clone could be used as a susceptible control for

Table 5. Host status of selected sweetpotato genotypes ${ }^{\mathrm{z}}$ to 12 populations of Meloidogyne incognita ${ }^{\mathrm{y}}$ collected worldwide.

\begin{tabular}{|c|c|c|c|c|c|c|c|c|c|c|c|c|c|c|c|}
\hline \multirow{3}{*}{$\begin{array}{l}\text { Root-knot } \\
\text { nematode } \\
\text { host race }\end{array}$} & \multirow{3}{*}{$\begin{array}{c}\text { Site of } \\
\text { collection }\end{array}$} & \multicolumn{14}{|c|}{ Sweetpotato genotype } \\
\hline & & \multicolumn{2}{|c|}{ Beauregard } & \multicolumn{2}{|c|}{ L86-33 } & \multicolumn{2}{|c|}{ PDM P6 } & \multicolumn{2}{|c|}{$\begin{array}{l}\text { Pelican } \\
\text { Processor }\end{array}$} & \multicolumn{2}{|c|}{ Porto Rico } & \multicolumn{2}{|c|}{ Tanzania } & \multicolumn{2}{|c|}{ Wagabolige } \\
\hline & & $\mathrm{EM}^{\mathrm{x}}$ & $\mathrm{SE}^{\mathrm{W}}$ & $\overline{\mathrm{EM}}$ & $\overline{\mathrm{SE}}$ & $\overline{\mathrm{EM}}$ & $\overline{\mathrm{SE}}$ & $\overline{\mathrm{EM}}$ & $\overline{\mathrm{SE}}$ & $\overline{\mathrm{EM}}$ & $\overline{\mathrm{SE}}$ & $\overline{\mathrm{EM}}$ & $\overline{\mathrm{SE}}$ & EM & $\overline{\mathrm{SE}}$ \\
\hline \multirow{2}{*}{ M. incognita 1} & Chinau $^{u}$ & $21 \mathrm{a}$ & 0.3 & $10 \mathrm{a}$ & 0.1 & $15 \mathrm{a}$ & 0.5 & $1 \mathrm{a}$ & 0 & $0 \mathrm{c}$ & 0.2 & $0 \mathrm{a}$ & 0 & $0 \mathrm{a}$ & 0 \\
\hline & NC-U.S. & $37 \mathrm{a}$ & 0.3 & $26 \mathrm{a}$ & 0.3 & $22 \mathrm{a}$ & 0.3 & $1 \mathrm{a}$ & 1.0 & $43 \mathrm{a}$ & 0.5 & $0 \mathrm{a}$ & 0 & $1 \mathrm{a}$ & 0 \\
\hline M. incognita 2 & Nigeria & $19 \mathrm{~b}$ & 0.9 & $6 \mathrm{~b}$ & 0.3 & $13 \mathrm{~b}$ & 0.2 & $0 \mathrm{~b}$ & 0 & $2 \mathrm{~b}$ & 0.1 & $3 \mathrm{a}$ & 0.1 & $0 \mathrm{a}$ & 0 \\
\hline \multirow[t]{3}{*}{ M. incognita 3} & La.-U.S. & $40 \mathrm{a}$ & 0.2 & $10 \mathrm{~b}$ & 0.1 & $30 \mathrm{a}$ & 0.4 & $1 \mathrm{a}$ & 0 & $3 b$ & 0.1 & $2 \mathrm{a}$ & 0 & $0 \mathrm{a}$ & 0 \\
\hline & Uruguay & $48 \mathrm{a}$ & 1.0 & $25 \mathrm{a}$ & 0.2 & $25 \mathrm{a}$ & 0.3 & $0 \mathrm{a}$ & 0 & $0 \mathrm{~b}$ & 0 & $2 \mathrm{a}$ & 0.1 & $0 \mathrm{~b}$ & 0 \\
\hline & NC-U.S. & $26 \mathrm{a}$ & 0.2 & $6 \mathrm{~b}$ & 0.1 & $6 \mathrm{~b}$ & 0.1 & $0 \mathrm{a}$ & 0 & $13 \mathrm{a}$ & 0.3 & $0 \mathrm{~b}$ & 0 & $0 \mathrm{~b}$ & 0 \\
\hline \multirow[t]{3}{*}{ M. incognita 4} & TX-U.S. & $46 \mathrm{a}$ & 0.7 & $13 \mathrm{ab}$ & 0.1 & $25 \mathrm{a}$ & 0.3 & $18 \mathrm{~b}$ & 0.2 & $2 b$ & 0 & $1 \mathrm{a}$ & 0.2 & $0 \mathrm{~b}$ & 0 \\
\hline & Ghana & $33 \mathrm{a}$ & 0.3 & $11 \mathrm{~b}$ & 0.1 & $25 \mathrm{a}$ & 0.2 & $43 \mathrm{a}$ & 0.2 & $29 \mathrm{a}$ & 1.4 & $1 \mathrm{a}$ & 0.2 & $1 \mathrm{a}$ & 0.3 \\
\hline & NC-U.S. & $48 \mathrm{a}$ & 0.5 & $21 \mathrm{a}$ & 0.2 & $28 \mathrm{a}$ & 0.1 & $0 \mathrm{c}$ & 0 & $1 \mathrm{~b}$ & 0 & $1 \mathrm{a}$ & 0.3 & $0 \mathrm{ab}$ & 0 \\
\hline
\end{tabular}

${ }^{2}$ Sweetpotato genotypes selected for their differential response to the four Meloidogyne incognita host races from the greenhouse cultures in the Nematology program at NC State Univ.

${ }^{y}$ Nematode populations were collected by scientists participating in the International Meloidogyne Project and kept frozen in liquid nitrogen. Populations from NC were not subjected to cryogenic storage. Race designation is based upon NC Differential Host Test (Hartman and Sasser, 1985).

${ }^{x}$ Number of egg masses (EM) produced by the nematodes per root system. EM is the back-transformed mean of two tests of five replications each. Transformation used for data analysis was $\sqrt{(x+0.5)}$.

"Wtandard error of the mean for EM.

'For each RKN host race group, values within a column followed by the same letter are not significantly different (Fisher's protected LSD test, $\alpha=0.05$ ).

"EM mean and significance value for $M$. incognita race 1 from China is based only on one test of five replications. 
screening purposes because of this broad susceptibility. 'Beauregard' is the predominant cultivar in the United States, occupying roughly $70 \%$ of total U.S. acreage, and it has been used as a parental line in the United States and in many countries. The susceptibility of 'Beauregard' to root-knot nematode should be taken into account by breeders. Resistance is the most economically efficient and sustainable method of controlling nematodes. Because virulent nematode biotypes typically spread at a very slow rate, it is reasonable to expect that a durable, resistant cultivar could be efficiently deployed with the appropriate knowledge of the nematode pathotype(s) present in the field (Goplen et al., 1959). However, the genetic complexity of sweetpotato will undoubtedly complicate the plant-pathogen interactions and hence breeding progress. Further, the differential susceptibility (i.e. none, low, medium, and high infection levels) of the selected genotypes suggests that root-knot nematode resistance in sweetpotato is, at least in some cases, quantitative. This observation is supported by studies of Giamalva et al. (1963), Davide and Struble (1966), and Lawrence and Clark (1986).

It might be beneficial to develop a set of sweetpotato differential host genotypes for $M$. incognita, $M$. arenaria, and $M$. javanica. We have contributed to this effort, but unfortunately none of the genotypes we evaluated were capable of differentiating races 1 and 3 of the North Carolina populations of $M$. incognita. However, a clear differentiation was observed for the other Meloidogyne populations. When the seven selected sweetpotato genotypes were tested against the $12 \mathrm{M}$. incognita populations, differences in virulence were observed within each designated $M$. incognita host race (Hartman and Sasser, 1985).

Developing a better understanding of the sources and relationships of the genes for resistance in sweetpotato and nematode virulence is warranted given the differences in virulence observed among the $M$. incognita populations worldwide. The two East African landrace sweetpotatoes ('Tanzania' and 'Wagabolige') appear to be especially valuable germplasm as they possessed high levels of resistance to all Meloidogyne populations tested. These high dry matter $(\approx 30 \%)$, whitefleshed genotypes, which also exhibit resistance to Sweetpotato virus disease (Mwanga, 2001), need to be further investigated to determine the nature of this broad-spectrum resistance, which could be used to improve the levels of root-knot nematode and virus resistance in sweetpotato cultivars.

Finally, our work may explain some of the differences in resistance to root-knot nema- todes observed among different sweetpotato breeding programs in the United States (K.V. Pecota, personal communication), and the breakdown of resistance when clones are tested in different countries with varying root-knot nematode populations. We hope the results presented here will contribute to our understanding of nematode population structure and host resistance in sweetpotato worldwide, and contribute to the improvement of the evaluation of root-knot nematode resistance in sweetpotato breeding programs.

\section{Literature Cited}

Bonsi, C.K. and B.R. Phills. 1979. Reaction of twelve sweetpotato cultivars and breeding lines to two root-knot species with three experimental methods. HortScience 14(4):539-541.

Cervantes-Flores, J.C., E.L. Davis, and G.C. Yencho. 2000. Evaluation of resistance to root-knot nematodes in selected sweetpotato cultivars. Nematropica 30(2):117 (Abstr.).

Clark, C.A., P.D. Dukes, and J.W. Moyer. 1992. Diseases, p. 88-105. In: A. Jones and J.C. Bouwkamp (eds.). Fifty years of cooperative sweetpotato research 1939-1989. Southern Coop. Ser. Bul. No. 369.

Cordner, H.B., F.B. Struble, and L. Morrison. 1954. Breeding sweetpotatoes for resistance to the root-knot nematode. Plant Dis. Rptr. Suppl. 227:92-93.

Davide, R.G. and F.B. Struble. 1966. Selection from a field population for variability in Meloidogyne incognita on sweetpotato. Philippine Agriculturist 50:15-29.

Davis, E.L., D.M. Meyers, J.W. Burton, and K.R. Barker. 1998. Resistance to root-knot, reniform, and soybean cyst nematodes in selected breeding lines. Suppl. J. Nematol. 30(4S):530-541.

Davis, E.L., J.R. Rich, G.R. Gwynn, and V. Sisson. 1988. Greenhouse evaluation of Nicotiana spp. for resistance to root-knot nematodes. Nematropica 18(2):99-107.

Daykin, M.E. and R.S. Hussey. 1985. Staining and histopathological techniques in nematology, $\mathrm{p}$. 39-48. In: K.R. Barker, C.C. Carter, and J.N. Sasser (eds.). An advanced treatise on Meloidogyne. Vol. II: Methodology. NCSU Graphics, Raleigh, N.C.

Giamalva, M.J., T.P. Hernandez, W.J. Martin, and J.C. Miller. 1961. Testing sweetpotato progenies for nematode resistance. Proc. Ann. Convention Assn. Southern Agr. Workers 58:174 (Abstr.).

Giamalva, M.J., W.J. Martin, and T.P. Hernandez. 1963. Sweetpotato varietal reaction to species and races of root-knot nematodes. Phytopathology 53:1187-1189.

Goplen, B.P., E.H. Stanford, and M.W. Allen. 1959. Demonstration of physiological races within three root-knot nematode species attacking alfalfa. Phytopathology 49:653-656.

Hartman, K.M. and J.N. Sasser. 1985. Identification of Meloidogyne species on the basis of differential host test and perineal-pattern morphology, p. 69-77. In: K.R. Barker, C.C. Carter, and J.N. Sasser (eds.). An advanced treatise on Meloidogyne. Vol. II: Methodology. NCSU Graphics, Raleigh, N.C.

Hussey, R.S. and K.R. Barker. 1973. A comparison of methods of collecting inocula for Meloidogyne spp., including a new technique. Plant Dis. Rptr. 57:1025-1028.

Jones, A. and P.D. Dukes. 1980. Heritabilities of sweetpotato resistances to root-knot caused by Meloidogyne incognita and M. javanica. J. Amer. Soc. Hort. Sci. 105(2):154-156.

Jones, A., P.D. Dukes, J.M. Schalk, and M.G. Hamilton. 1991. I/13 and J/8 sweetpotato mass selection populations. HortScience 26(7):929 930.

Lawrence, G.W. and C.A. Clark. 1986. Identification, race determination, and pathogenicity of root-knot nematodes to resistant and susceptible sweetpotatoes. J. Nematol. 18:617 (Abstr.).

Lawrence, G.W., C.A. Clark, and V.L. Wright. 1986. Influence of Meloidogyne incognita on resistant and susceptible sweetpotato cultivars. J. Nematol. 18(1):59-65.

Mwanga, R.O.M. 2001. Nature of resistance of sweetpotato to sweetpotato virus disease. $\mathrm{PhD}$ Diss., North Carolina State Univ., Raleigh.

Netscher, C. and D.P. Taylor. 1979. Physiologic variation with the genus Meloidogyne and its implications on integrated control, p. 269-294. In: F. Lamberti and C.E. Taylor (eds.). Rootknot nematodes (Meloidogyne species) systematics, biology and control. Acad. Press, London.

Roberts, P.A. 1992. Current status of the availability, development, and use of host plant resistance to nematodes. J. Nematol. 24(2):213-227.

Roberts, P.A. 1995. Conceptual and practical aspects of variability in root-knot nematodes related to host plant resistance. Annu. Rev. Phytopathol. 33:199-221.

Sasser, J.N. 1980. Root-knot nematodes: a global menace to crop production. Plant Dis. 64(1):3641.

Sasser, J.N. and C.C. Carter. 1985. Overview of the international Meloidogyne project 1975-84, p. 19-24. In: J.N. Sasser and C.C. Carter (eds.). An advanced treatise on Meloidogyne. Vol. I: Biology and control. NCSU Graphics, Raleigh, N.C.

Struble, F.B., L.S. Morrison, and H.B. Cordner. 1966. Inheritance of resistance to stem rot and root knot nematode in sweetpotato. Phytopathology 56:1217-1219.

Taylor, A.L., J.N. Sasser, and L.A. Nelson. 1982 Relationship of climate and soil characteristics to geographical distribution of Meloidogyne species in agricultural soils. Intl. Meloidogyne Project, Raleigh, N.C

Toth, S.J. Jr., C.W. Averre, D.W. Monks, J.R. Schultheis, and K.A. Sorensen. 1996. Sweetpotato Pest Management 1991: A survey of pesticide use and other pest management practices by North Carolina sweetpotato producers. N.C. Coop. Ext. Serv., Raleigh.

Ukoskit, K., P.G. Thompson, and C.E. Watson, Jr. 1997. Identifying a randomly amplified polymorphic DNA (RAPD) marker linked to a gene for root-knot nematode resistance in sweetpotato. J. Amer. Soc. Hort. Sci. 122(6):818-821. 